\title{
A Review of Main Strands on the Flow-Performance Relationship of Mutual Funds
}

\begin{abstract}
By Dariusz Filip*
This paper is a review of literature for findings on the flow-performance relationship of mutual funds. It is noted that the discussed issue has been examined virtually exclusively in developed countries. There are no or only fragmentary findings of this kind in developing economies. Based on a survey of empirical findings, it is possible to outline the main directions of research within the strands examined by contemporary researchers and explain the basic assumptions when formulating hypotheses. Moreover, the evaluation of the existing literature lets to offer several propositions for future research. It is a preliminary paper that systematises the analysed subject matter and an introduction to an empirical study dedicated to small European mutual fund markets.
\end{abstract}

Keywords: mutual funds, performance, net flows, individual investors, behavioral finance

\section{Introduction}

Activities performed by various types of financial intermediaries have captured the attention of business analysts, investors and academics for many years now. Early studies of mutual funds (e.g. Treynor 1965, Horowitz 1965, Sharpe 1966, Jensen 1968) analyzed fund managers' skills of generating superior returns. By and large, the obtained results showed that active asset managers were unable to add value to investors and outperform the market portfolio, which was supported by the later efficient market hypothesis.

However, some more recent studies provided more ambiguous findings. For instance, Ippolito (1989), Grinblatt and Titman (1993), and Goetzmann and Ibbotson (1994) showed that some mutual funds were able to achieve superior risk-adjusted returns. The research discussion led to subsequent conclusions providing that net returns proved to be lower than the rate of return on the market portfolio if management fees were taken into account (Grinblatt et al. 1995, Daniel et al. 1997).

On the other hand, the occurrence of performance persistence, which might have resulted from managerial skills or utilization of market factors, began to be noticed in the relevant literature (Grinblatt and Titman 1992, Hendricks et al. 1993, Carhart 1997, Du et al. 2009). If managers are skilled in stock selection or market timing, it can be expected that they will be able to maintain investment results at similar levels in successive periods. Given the issues that are significant

*Assistant Professor, Department of Finance, Cardinal Stefan Wyszynski University in Warsaw (UKSW), Poland. 
to investors, that is the assumption that past performance might not be random and could be persistent, predicting future rates of return based on past results seems interesting.

Although the U.S. Securities and Exchange Commission (SEC) states that "past performance is not indicative of future results", earlier returns might be one of the most common reasons for investing new money on capital markets (e.g., Lakonishok et al. 1992). Empirical investigations on the Flow-Performance Relationship (FPR) have earned a place in the history of research on mutual fund performance.

The main aim of this paper is to provide a critical review of the main strands of literature on the flow-performance relationship of mutual funds measures. By reviewing more than 60 references, the authors intend to present the justification for studies dedicated to the analysed relationship (FPR), indicate the domiciliation where the discussed subject matter was analysed, and signalise the need of further research in emerging markets, such as small European economies. It is an introductory study that synthetises certain issues, which will make it possible to clarify the basic assumptions when formulating the main theses in successive works. Although it is difficult to provide new knowledge at this stage, the paper describes the research gaps and raises several research questions that will be filled during the future research.

Apart from the introduction, this paper is composed of four major sections. First of all, studies of the main strand of literature concerning sensitivity of fund flows to past performance are discussed. Based on the findings to date, the direction for further research related to the existence of the convexity of the flowperformance relationship is identified in part three. The next section presents two opposing hypotheses as part of performance anticipation and findings in this area to date, i.e., the "smart money" effect and the "dumb money" effect. The review is conducted on the basis of the most popular and cited articles. The text is closed with a brief summary of the literature findings and indicating needs for additional research and propositions.

\section{Main Strand in the Literature Concerning Sensitivity of Fund Flows to Past Performance}

Mutual funds have become an important part of financial markets over the past few decades, from the perspective of both individual clients who invest their money and companies in which the entrusted assets are put. Due to the growing number of entities in the market of mutual funds, their clients have an increasingly wider array of collective investment institutions and services. Despite such a diversity of products, the factors by which investors are guided when selecting funds have not been fully described yet.

The discussed issue refers to the above-mentioned strand in the literature, namely one concerned with performance persistence, which was concentrated mainly in low-liquidity sectors or at shorter horizons. It is the results obtained there (e.g., Brown et al. 1992, Brown and Goetzmann 1995, Malkiel 1995, Elton et 
al. 1996) that sparked the investigations on the flow-performance relationship. As a rule, the performance generated by fund managers does not result from earlier investment returns, i.e., it is hard to predict them relying on historical data only. Nonetheless, investors might chase performance when making their investment decisions.

At the end of the 1970s and the beginning of the 1980s, it was noticed that flows into and out of financial markets were strongly correlated with past performance (Spitz 1970, Smith 1978, De Bondt and Thaler 1985). One of the first studies showing that mutual fund investors tend to base their purchase decisions on prior risk-adjusted returns were, among others, Kane et al. (1991), Patel et al. (1994) and Roston (1996). They revealed that the aggregate pattern of consumer investing behavior seemed rational. Sirri and Tufano (1998) defined performance as a factor with the greatest impact on investment decisions, where advertisement or search costs were less significant for investors. The above gave rise to a popular belief that funds with superior performance would attract more new assets, while those with inferior performance would experience more outflows. The issue was named the FPR. However, in the first half of the 1990s, some researchers started to notice that a status-quo bias made investors ignore information about bad fund performance (see Zeckhauser et al., 1991).

The relationship was examined in many studies from developed markets, in particular from the U.S.A. (Ippolito 1992, Chevalier and Ellison 1997, Christoffersen 2001), and in much fewer works from developing economies (cf., Steinberg and Porath 2013, Lemeshko 2016). In general, the obtained results have encouraged the conclusions that capital flows are sensitive to past performance, which means that flows into a fund are higher when the prior returns of the fund were better.

For instance, Wilcox (2003) signalized that prior returns, especially in the long run, were a factor that was most frequently analyzed by investors when selecting a fund. As a result of intensified current market information, some studies indicated, in turn, that the present fund performance was more important in shaping clients' decisions than long-term returns (Levy and Levy 2003). Goriaev et al. (2002) found evidence that individual investors responded to results with a certain lag. As was shown, the returns from the previous 2-3 quarters had a substantially stronger impact on net flows than the performance of the last quarter for investors in the U.S. market. Moreover, taking risk into account in returns translates into capital flows to a small extent, which implies that some investors are style timers and choose funds mainly on the basis of raw returns rather than risk-adjusted returns.

Berk and $\mathrm{Xu}$ (2004) made an observation that when a fund underperformed, only responsive investors were able to react by withdrawing money. Less responsive investors seemed to be more indulgent to inferior returns. Where poor performance persisted for two years in a row, capital outflows were statistically insignificant. Coval and Stafford (2007) and Zhang (2009) noted, however, that funds with large outflows faced poorer performance, which was attributed to price pressure in the stocks they sold. 
As regards small markets, e.g., the Iberian Peninsula, results indicate that inflows do not respond to the rates of return achieved in the previous calendar year (Alves and Mendes 2007). For retail and wholesale segments, in turn, Gupta and Jithendranathan (2012) noticed, on the example of Australian mutual funds, that investors based their investment choices on past performance. When making their investment decisions, clients were guided by a fund's past performance with the retail segment being more sensitive to that indicator than the wholesale segment. Ferreira et al. (2012), in turn, pointed to differences in the FPR across countries. It was determined that investors from more developed countries sold loser funds more often than bought winner funds. This is because investors in these countries were more sophisticated and were able to face lower costs of participation in mutual funds. Moreover, Alves and Mendes (2011) noticed that no response to past returns could result from lower complexity of the discussed financial market or existence of search costs involved, among others, with limited dissemination of information about fund performance. In general, the achieved results and failure to associate performance with asset flows in the next period might indicate lower responsiveness or unsophisticated knowledge of economics among investors from developing markets. The case of differences in popularity, and therefore net sales, in developing European markets could be considered as an example (e.g., Trzebiński 2018). Figure 1 presents values of net sales of small mutual fund industries (the left scale) plotted with value of total European net sales (the right scale).

Figure 1. Net Sales of UCITS Funds from the Developing European Industries

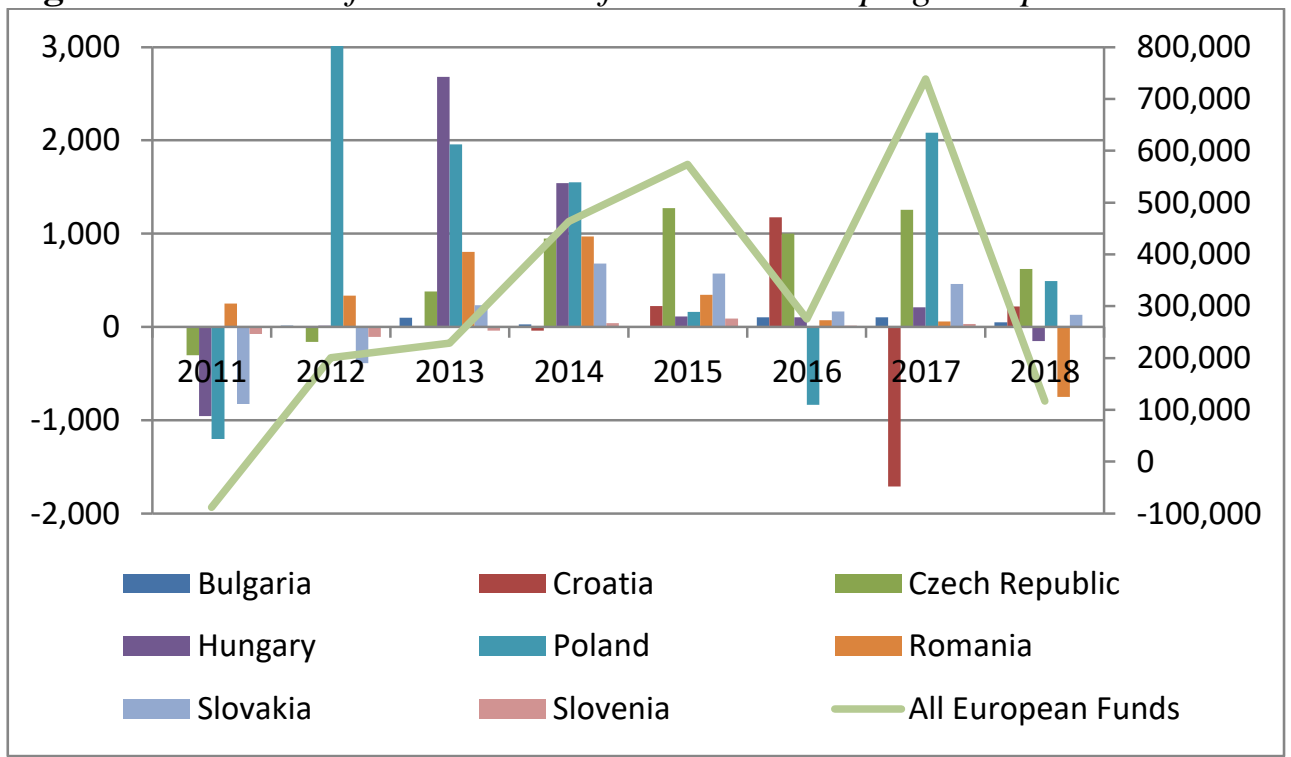

Source: Own compilation on the basis of Quarterly Statistical Releases (2011-2018) of the European Fund and Asset Management Association (EFAMA).

Note: data presented in millions of euro.

Capon et al. (1996) noticed that investors could be characterized by different levels of informational engagement in a given investment depending on the decision criteria they applied. A vast majority of them focused primarily on past 
performance, while others - on issues related to participation costs - they were the so-called price-sensitive investors. A significant minority, in turn, concentrated mainly on the quality of the service provided by a fund - they were the so-called non-price sensitive investors. The mentioned authors pointed also to the fact that certain investors were remarkably uninformed, even as regards the entities they had chosen. This was manifested in some of them being unaware even of whether the fund they selected was a load fund or what the fund's investment objectives were.

As evidenced in many studies, institutional investors are more sophisticated and have a better understanding of fund attributes (Evans and Fahlenbrach 2012, Akbas et al. 2015), while retail investors are viewed to exhibit various behavioral biases, such as the disposition effect (Odean 1998). Del Guercio and Tkac (2002), in turn, pointed to the diversity of the FPR. In comparison to mutual fund participants, clients of pension funds punish poorly performing ones by withdrawing assets under management but, on the other hand, they do not automatically flock to recent winners. Mutual fund investors, in turn, tend to direct their cash flows to recent winners disregarding risk-adjusted performance measures. Therefore, it is possible to formulate first research question: Is there a tendency to observe the higher the past performance of a fund in regard to the higher its net flows of mutual funds in developing markets.

Capital flow data reveal direct investor preferences when selecting a fund. As was indicated above, a majority of them might chase the returns generated to date. The results described in the finance literature show that both raw returns and riskadjusted returns can affect flows in successive periods. There are studies showing that several performance measurement methods could simultaneously influence net flows (e.g., Ippolito 1992, Gruber 1996, Chevalier and Ellison 1997). Nevertheless, Sirri and Tufano (1992) demonstrated that it was chiefly raw returns that were a driver of assets from retail clients to mutual funds. They interpreted this phenomenon as "naive trend chasers", who made their investment decisions based on noisier measures of performance. Patel et al. (1994), in turn, reported that prior risk-adjusted performance could be related to capital flows. A different view can be found in the study by Ivkovic and Weisbenner (2009). They distinguished the sensitivity of inflows and outflows to relative and absolute performance, respectively.

Del Guercio and Tkac (2002), who were mentioned above, showed that mutual fund investors used less sophisticated measures of returns than pension fund clients. As regards the former market, it is noticeable that less sophisticated investors are less responsive to multifactor models explaining mutual fund performance, which means that they chase only raw returns (see Bailey et al. 2011). In fact, however, investors should allow also for alpha estimates from asset pricing models when intending to allocate capital to funds. For instance, Huang et al. (2012) agreed that a more precise assessment of fund performance was more appropriate for sophisticated investors and could considerably impact net flows. Similarly, Barber et al. (2016) noticed that CAPM alphas were the best predictor of flow among a set of various available measures. They established that greater net flows to mutual funds were related to a higher rank based on alphas rather than 
to comparative analysis employing different measures. In connection with the said results, Arbaa et al. (2017) showed, for a small market, that clients of mutual funds were more sensitive to risk-adjusted returns than absolute ones. They noticed that investors from developed countries in the Middle East appreciated performance measured with Sharpe ratios and alphas more than raw returns. This leads us to rise second research question considered in developing countries: Do risk-adjusted past returns influence net flows more than raw returns.

In the studies dedicated to the FPR, more sophisticated measures of returns, such as the Carhart ratio or market timing measures, are rarely applied. Therefore, the investigations engaging a set of extensive ratios seem desirable in the context of analyzing sensitivity and robustness of the obtained results to the applied measurement procedures.

\section{Convexity of the Flow-Performance Relationship}

Early studies established that past performance was an important factor determining net flows into funds. However, the issues that intrigued academics included the diversity of client reactions to higher and lower performance. A large number of researches have shown that the FPR is nonlinear, thus providing evidence that investors buy funds with good past performance but at the same time do not leave funds with poor returns (e.g., Ippolito 1992, Chevalier and Ellison 1997, Christoffersen 2001). For instance, Sirri and Tufano (1998), by means of a piecewise linear specification, found some convexity, where the relationship between flows and past performance was concentrated mainly on the highest performing funds. In other words, funds with superior recent performance experienced disproportionately greater inflows, while funds with poor performance suffered smaller outflows. Also Chevalier and Ellison (1997), who employed semi-parametric specification, proved that mutual fund investors made unit purchase decisions based on prior returns but do it asymmetrically, investing more in top performing funds, while showing little or no response to lower performing funds. Many other researchers, including ones examining less developed markets, drew similar conclusions (e.g., Arbaa et al. 2017).

In accordance with the previously documented findings, Pagani et al. (2011) indicated that, apart from the FPR convexity, looking at mutual funds from the viewpoint of their managers' skills could also be convex with respect to new asset inflows. Huang et al. (2007), in turn, applied the Fama-MacBeth procedure to show that the convexity of the FPR declined over time for U.S. mutual funds. They argued this was a result of a decrease in participation costs due to investors becoming increasingly better informed.

The causes of the phenomenon consisting in rewarding better performing mutual funds by increasing net flows into those funds and at the same time not punishing past losers with outflows can be attributed to the existence of numerous institutional and behavioral factors, which reduce such flows out of funds. Moreover, market considerations, such as the presence of search costs, load charges, or tax patterns, increase the transaction costs of withdrawing money from 
poorly performing funds (cf., Sirri and Tufano 1998). Goetzmann and Peles (1997), who found a substantial relationship between flows and past returns, albeit only for the top quartile of past performance, pointed to the existence of a cognitive dissonance bias, which makes investors ignore the information about bad fund performance. They showed that investors were positively biased in remembering the past performance of the fund they chose. Lynch and Musto (2003) looked for arguments in favor of the existence of the FPR convexity in the relative expectation theory. According to them, investors might be unwilling to sell poorly performing funds because they expect underperforming funds to radically modify their investment strategies or change managers soon.

It should also be noted that the hump-shaped relationship was observed in both developed and smaller, less sophisticated, markets. As was showed by Ferreira et al. (2012), analyzing the relationship between flows and performance in 28 countries, the convexity of the relationship was discerned in the world, yet its degree of flatness is different across countries. Therefore, it was possible to establish third research question: Is there a non-linear relationship between past performance and fund flows.

\section{Performance Anticipation Hypothesis}

The finance literature documents a significantly positive relationship between mutual fund flow and future performance. One of the first authors to discern this phenomenon was Gruber (1996), who noticed that investors had the ability to select funds which would be able to achieve superior performance in the next period. It means that mutual funds with net inflows outperform those with net outflows. As regards investors themselves, it was suggested that there might be informed investors capable of forecasting future investment results based on the information about past returns, who put their savings in funds with better future performance. Similarly, Zheng (1999) confirmed the relation and indicated that funds which received greater net flows outperform their less popular peers in the next period. Apart from confirming the Gruber's pattern, she also found the existence of a short-term information effect, which means that an aggregate new money flow had the information that could be used to generate superior returns. Both these studies introduced the term "smart-money" effect to the relevant literature and defined it as mutual fund investors' ability to predict short-term performance and invest by moving money from underperformers to funds with better investment results.

Later studies pondered on the question whether the captured "smart money" effect was an outcome of a manager's talent or a momentum in rates of return. For instance, Sapp and Tiwari (2004) established that subsequent fund performance was adjusted to the momentum factor in stock returns and higher net flows stopped leading to better results. The finding refers to the observation of Jegadeesh and Titman (1993), who noticed that the stocks that performed well tended to continue doing well. Hence, investors were inclined to put their money into past winners. Therefore, after buying past winning funds, investors unwittingly benefit 
from momentum returns on winning stocks. The presence of momentum trading by mutual funds means that investors have no fund selection ability. Wermers (2003) noticed that fund managers who had recently performed well tried to perpetuate this performance by investing a large proportion of the new money they received in the stocks that had lately generated good returns.

Wermers's observation that clients heavily invest in the last year's winning funds, and the managers of such winners invest the received inflows in momentum stocks in order to continue superior performance, was broadly discussed. The literature concerning anomalies in financial markets (e.g., Dacey and Zielonka 2013, Bóta and Ormos 2017) notices that managers of losing portfolios seem reluctant to sell their losing stocks and to purchase the new momentum stocks probably due to the disposition effect. Normally, the effect consists in investors' tendency to sell winning stocks to soon and hold losing stocks too long.

However further researches (e.g., Frazzini and Lamont 2006, Friesen and Sapp 2007) noticed, contrary to what Gruber and Zheng argued, that a large group of investors were less informed and less sophisticated than it would seem. Their activities in the form of investments in funds generated poor performance in the long run. The mentioned authors stated that fund net flows resulted in the so-called "dumb money" effect and investors themselves had low timing abilities, i.e., an average individual investor made wrong investment decisions most of the time. Teo and Woo (2004) also obtained evidence of the "dumb money" effect, which was reflected in high inflow funds underperforming low inflow funds over multiyear time periods. Similarly, Edelen (1999) documented that the results achieved by a fund deteriorated when a massive inflow of new capital forced managers to engage in liquidity-motivated trading.

The verification of the hypothesis on performance reaction was conducted also in non-U.S. markets. For example, Keswani and Stolin (2008) decided to investigate monthly capital inflows and outflows among UK mutual funds. They pointed to the existence of a robust "smart money" effect. It was caused by unit buying rather than selling decisions. Nonetheless, for a less developed industry, such as the Portugal market, Alves and Mendes (2011) rejected the smart and the dumb money hypotheses. They showed that capital flows in one period were independent of the fund performance in the following period. Given the above, the next research question risen in small European market is: Do fund net flows influence subsequent performance.

\section{Conclusion}

The contemporary international finance literature on the broadly defined FPR comprises dozens, if not hundreds, of titles. The set of findings in this stream is being expanded by recent studies, which introduce improvements in the applied research methods. The analysis of mutual fund investors' reaction to performance has been an object of investigation in large and developed markets, especially in the U.S.A. However, there are some reasons to assume that clients of collective investment institutions in small markets, such as chosen European mutual fund 
industries, might respond differently than investors in bigger, developed and more complex ones.

The conducted review is an attempt to describe this gap. Moreover, there is a need to offer several propositions for future studies from developing markets. The FPR issues raise several research questions. Is there a tendency to observe the higher the past performance of a fund in regard to the higher its net flows? Do risk-adjusted past returns influence net flows more than raw returns? Is there a non-linear relationship between past performance and fund flows? Do fund net flows influence subsequent performance? Taking the above into account, there is a preliminary paper that systematises the analysed subject matter and an introduction to an empirical study dedicated to small European mutual fund markets.

As shown in the literature review, large and small markets vary in terms of the complexity and sensitivity of investors, which in turn could result in diverse client behaviors. In small markets with considerably lower complexity, a smoothed FPR can be noticed as fund clients can classify funds as outperformers and underperformers much more easily when using the search cost criterion. On the other hand, it could be also hypothesized that in small, less complex and less competitive markets, where conflicts of interests (investor vs. fund manager) might be stronger, the presence of unsophisticated investors can result in a lower convexity of the market or absence of any reaction of investors.

To conclude, the analysis of the FPR resulted in noticing many effects which, in broad terms, are regarded as market anomalies (cf., Brown and Wu 2016, Kamstra et al. 2017). The emerging research perspective for small European financial markets, which is dynamically developing yet is still associated with e.g. a low value of assets under management and a limited number of financial intermediaries, makes the issue of chasing performance by investors and the verification of any spillover effects seem cognitively and socially justified.

\section{References}

Akbas F, Armstrong WJ, Sorescu S, Subrahmanyam A (2015) Smart-money, dumb money, and capital market anomalies. Journal of Financial Economics 118(2): 355-382.

Alves C, Mendes V (2007) Are mutual funds investors in jail? Applied Financial Economics 17(16): 1301-1312.

Alves C, Mendes V (2011) Does performance explain mutual fund flows in small markets? The case of Portugal. Portuguese Economic Journal 10(Aug): 129-147.

Arbaa O, Varon E, Benzion U (2017) The Effect of Performance on Israeli Equity Fund Flows. Accounting and Finance Research 6(4): 272-284.

Bailey W, Kumar A, Ng D (2011) Behavioral biases of mutual fund investors. Journal of Financial Economics 102(1): 1-27.

Barber BM, Huang X, Odean T (2016) Which factors matter to investors? Evidence from mutual fund flows. Review of Financial Studies 29(10): 2600-2642.

Berk JB, Xu J (2004) Persistence and fund flows of the worst performing mutual funds. NBER working paper. Cambridge.

Bóta G, Ormos M (2017) Determinants of the performance of investment funds managed in Hungary. Economic Research-Ekonomska Istraživanja 30(1): 140-153. 
Brown SJ, Goetzmann WN (1995) Performance Persistence. The Journal of Finance 50(2): 679-698.

Brown S, Goetzmann W, Ibbotson R, Ross S (1992) Survivorship bias in performance studies. Review of Financial Studies 5(4): 553-580.

Brown DP, Wu Y (2016) Mutual fund flows and cross-fund learning within families. The Journal of Finance 71(1): 383-424.

Capon N, Fitzsimons G, Prince R (1996) An individual level analysis of the mutual fund investment decision. Journal of Financial Services Research 10(1): 59-82.

Carhart MM (1997) On persistence in mutual fund performance. Journal of Finance 52(1): 57-82.

Chevalier J, Ellison G (1997) Risk taking by mutual funds as a response to incentives. Journal of Political Economy 105(6): 1167-1200.

Christoffersen S (2001) Why do money fund managers voluntarily waive their fees? Journal of Finance 56(3): 1117-1140.

Coval J, Stafford E (2007) Asset fire sales (and purchases) in equity markets. Journal of Financial Economics 86(2): 479-512.

Dacey R, Zielonka P (2013) High volatility eliminates the disposition effect in a market crisis. Decyzje 20(Dec): 5-20.

Daniel K, Grinblatt M, Titman S, Wermers R (1997) Measuring mutual fund performance with characteristic-based benchmarks. The Journal of Finance 52(1): 1035-1058.

De Bondt WFM, Thaler R (1985) Does the stock market overreact? Journal of Finance 40(3): 793-805.

Del Guercio D, Tkac PA (2002) The determinants of the flow of funds of managed portfolios: mutual funds vs. pension funds. Journal of Financial and Quantitative Analysis 37(4): 523-557.

Du D, Huang Z, Blanchfield PJ (2009) Do fixed income mutual fund managers have managerial skills? The Quarterly Review of Economics and Finance 49(2): 378-397.

Edelen R (1999) Investor flows and the assessed performance of open-end mutual funds. Journal of Financial Economics 53(3): 439-466.

Elton EJ, Gruber MJ, Blake CR (1996) The persistence of risk-adjusted mutual fund persistence. Journal of Business 69(2): 133-157.

Evans RB, Fahlenbrach R (2012) Institutional investors and mutual fund governance: evidence from retail-institutional fund twins. Review of Financial Studies 25(12): 3530-3569.

Ferreira MA, Keswani A, Miguel AF, Ramos SB (2012) The flow-performance relationship around the world. Journal of Banking and Finance 36(6): 1759-1780.

Frazzini A, Lamont O (2006) Dumb money: mutual fund flows and the cross-section of stock returns. NBER Working Paper 11526.

Friesen G, Sapp T (2007) Mutual fund flows and investor returns: an empirical examination of fund investor timing ability. Journal of Banking \& Finance 31(9): 2796-2816.

Goetzmann WN, Ibbotson RG (1994) Do winners repeat? Journal of Portfolio Management 20(2): 9-18.

Goetzmann W, Peles N (1997) Cognitive dissonance and mutual fund investors. Journal of Financial Research 20(2): 145-158.

Goriaev AP, Nijman TE, Werker BJM (2002) The dynamics of the impact of past performance on mutual fund flows. CentER Discussion Paper. Tilburg.

Grinblatt M, Titman S (1992) The persistence of mutual fund performance. The Journal of Finance 7(5): 1977-1984.

Grinblatt M, Titman S (1993) Performance measurement without benchmarks: An examination of mutual fund returns. Journal of Business 66(1): 47-68. 
Grinblatt M, Titman S, Wermers R (1995) Momentum investment strategies, portfolio performance, and herding: a study of mutual fund behavior. American Economic Review 85(5): 1088-1105.

Gruber M (1996) Another puzzle: the growth in actively managed mutual funds. Journal of Finance 51(3): 783-810.

Gupta R, Jithendranathan T (2012) Fund flows and past performance in Australian managed funds. Accounting Research Journal 25(2): 131-157.

Hendricks D, Patel J, Zeckhauser R (1993) Hot hands in mutual funds: Short-run persistence of relative performance, 1974-1988. Journal of Finance 48(1): 93-131.

Horowitz I (1965) A model for mutual fund evaluation. Industrial Management Review 6(2): 81-92.

Huang J, Wei KD, Yan H (2007) Participation costs and the sensitivity of fund flows to past performance. Journal of Finance 62(3): 1273-1311.

Huang JC, Wei KD, Yan H (2012) Investor learning and mutual fund flows. AFA 2012 Chicago Meetings Paper.

Ippolito R (1989) Efficiency with costly information: A study of mutual fund performance. Quarterly Journal of Economics 104(1): 1-23.

Ippolito R (1992) Consumer reaction to measures of poor quality: Evidence from the mutual fund industry. Journal of Law and Economics 35(1): 45-70.

Ivkovic Z, Weisbenner S (2009) Individual investor mutual fund flows. Journal of Financial Economics 92(2): 223-237.

Jegadeesh N, Titman S (1993) Returns to buying winners and selling losers: implications for stock market efficiency. Journal of Finance 48(1): 65-91.

Jensen MC (1968) The performance of mutual funds in the period of 1945-1964. Journal of Finance 23(May): 16-26.

Kamstra MJ, Kramer LA, Levi MD, Wermers R (2017) Seasonal asset allocation: evidence from mutual fund flows. Journal of Financial and Quantitative Analysis 52(1): 71-109.

Kane A, Santini D, Aber JW (1991) Lessons from the growth history of mutual funds. Working paper. USA: School of Management, Boston University.

Keswani A, Stolin D (2008) Which money is smart? Mutual fund buys and sells of individual and institutional investors. Journal of Finance 63(1): 85-118.

Lakonishok J, Shleifer A, Vishny RW (1992) The impact of institutional trading on stock prices. Journal of Financial Economics 32(1): 23-43.

Lemeshko O (2016) Determinants of mutual fund flows: Evidence from equity funds from EU. In SGEM Conference Proceedings - Volume III. Bulgaria: SGEM, 167-174.

Levy H, Levy M (2003) Overweighing recent observation: Experimental results and economic implications. Experimental Business Research 3(7): 155-183.

Lynch A, Musto D (2003) How investors interpret past fund returns. Journal of Finance 58(5): 2033-2058.

Malkiel BG (1995) Returns from investing in equity mutual funds 1971 to 1991 . The Journal of Finance 50(2): 549-572.

Odean T (1998) Are investors reluctant to realize their losses? Journal of Finance 53(5): 1775-1798.

Pagani M, Hu P, Kale J, Subramanian A (2011) Fund flows, performance, managerial career concerns, and risk taking. Management Science 57(4): 628-646.

Patel J, Zeckhauser R, Hendricks D (1994) Investment flows and performance: evidence from mutual funds, cross border investments, and new issues. In R Sato, R Levich and R Ramachandran (eds.), Japan, Europe, and International Financial Markets: Analytical and Empirical Perspectives. New York: Cambridge University Press. 
Roston MN (1996) Mutual fund managers and life cycle risk: an empirical investigation. Working paper. USA: University of Chicago.

Sapp T, Tiwari A (2004) Does stock return momentum explain the 'smart money' effect? Journal of Finance 59(6): 2605-2622.

Sharpe W (1966) Mutual fund performance. Journal of Business 39(1): 119-138.

Sirri E, Tufano P (1992) Competition and change in the mutual fund industry. In III S Hayes (ed.), Financial services: perspectives and challenges, 181-214. Boston: Harvard Business School Press.

Sirri ER, Tufano P (1998) Costly search and mutual fund flows. The Journal of Finance 53(5): 1589-1622.

Smith KV (1978) Is fund growth related to fund performance? Journal of Portfolio Management 4(3): 49-54.

Spitz AE (1970) Mutual fund performance and cash inflow. Applied Economics 2(2): 141-145.

Steinberg N, Porath Y (2013) Chasing their tails: inflow momentum and yield chasing among provident fund investors in Israel. Israel Economic Review 99(1): 71-106.

Teo M, Woo S-J (2004) Style effects in the cross-section of stock returns. Journal of Financial Economics 74(2): 367-398.

Treynor J (1965) How to rate management of investment funds. Harvard Business Review 43(1): 63-75.

Trzebiński AA (2018) Changes in the names of Polish investment funds vs. fund flows. Annales Universitatis Mariae Curie-Sklodowska, sectio H - Oeconomia 52(2): 161170.

Wermers R (2003) Is money really "smart"? new evidence on the relation between mutual fund flows, manager behavior, and performance persistence. Working paper. USA: University of Maryland.

Wilcox R (2003) Bargain hunting or star gazing? Investors' preferences for stock mutual funds. Journal of Business 76(4): 645-663.

Zeckhauser R, Patel J, Hendricks D (1991) Nonrational actors and financial market behavior. Theory and Decision 31(2-3): 257-287.

Zhang H (2009) Asset fire sales, liquidity provision, and mutual fund performance. Working paper. USA: University of Texas.

Zheng L (1999) Is money smart? A study of mutual fund investors' fund selection ability. Journal of Finance 54(3): 901-933. 